\title{
CORN PRODUCTION FOR SILAGE INTERCROPPED WITH FORAGE IN THE FARMING-CATTLE BREEDING INTEGRATION ${ }^{1}$
}

\author{
VERIDIANA Z. DE MENDONÇA ${ }^{2}$, LUIZ M. M. DE MELLO ${ }^{3}$, FRANCISCO C. B. L. \\ PEREIRA $^{4}$, JOSÉ O. DA R. SILVA ${ }^{5}$, ÉLCIO H. YANO ${ }^{6}$
}

\begin{abstract}
Corn cropping for silage, due to the plant material exportation, intercropping with forage provides greater ground cover and straw formation for the Direct Planting System (DPS) continuity. The objective of this study was to evaluate corn production for silage in DPS intercropped with four forages (Urochloa brizantha cv. Marandu, U. ruziziensis cv. Ruziziensis, Panicum maximum cv. Tanzânia and P. maximum cv. Áries). We applied three sowing methods (in row together with corn fertilizer; by no-till sowing simultaneously to corn sowing and at V4 corn stage) and corn without intercropping. The experiment was conducted in autumn/ winter of 2010, in Selvíria - MS, in a randomized block design in factorial arrangement $(4 \times 3+1)$ and 4 replications. For corn, we evaluated plant height, basal stem diameter, initial and final stand and silage production and for forage dry matter production. Morphological characteristics and corn yield were not affected by intercropping when compared to sole corn crop. Forage dry matter production sown in corn row with fertilizer is a highlight, which in addition to providing greater productivity, harnesses the operation during sowing.
\end{abstract}

KEYWORDS: direct sowing, interspecific competition, sowing mode, mulching

\section{PRODUÇÃO DE MILHO PARA SILAGEM CONSORCIADO COM FORRAGEIRAS NA INTEGRAÇÃO LAVOURA-PECUÁRIA ${ }^{1}$}

RESUMO: Na cultura de milho para silagem, devido à exportação do material vegetal, a consorciação com forrageiras proporciona maior cobertura do solo e formação de palhada para a continuidade do Sistema Plantio Direto (SPD). O objetivo do trabalho foi avaliar a produção de milho para silagem, em SPD, consorciado com quatro forrageiras (Urochloa brizantha cv. Marandu, U. ruziziensis cv. Ruziziensis, Panicum maximum cv. Tanzânia e P. maximum cv. Áries), em três modalidades de semeadura (na linha, junto com o adubo do milho; a lanço simultâneo ao milho e a lanço no estádio V4 do milho) e milho sem consorciação. O experimento foi conduzido no outono/inverno de 2010, no município de Selvíria - MS, com delineamento em blocos casualizados, em esquema fatorial $(4 \times 3+1)$ e quatro repetições. Na cultura do milho, foram avaliados: altura de plantas, diâmetro basal do colmo, estande inicial e final, e produção de silagem, e, nas forrageiras, a produção de matéria seca. As características morfológicas e a produtividade de milho não foram influenciadas pelos consórcios quando comparados ao milho sem consorciação. Destaca-se a produção de matéria seca da forragem na modalidade de semeadura na linha do milho junto ao adubo, que além de proporcionar maior produtividade, aproveita a operação por ocasião da semeadura.

PALAVRAS-CHAVE: semeadura direta, competição interespecífica, modalidade de semeadura, palhada

\footnotetext{
${ }^{1}$ Paper extracted from the first author Master’s thesis under financing of Fundação Agricultura Sustentável (Sustainable Agriculture Foundation) - Agrisus.

${ }^{2}$ Eng $^{\mathrm{a}}$ Agrônoma, Doutoranda em Agronomia (Energia na Agricultura), Faculdade de Ciências Agronômicas, UNESP, Botucatu SP, Fone: (14) 3880-7203, veridianazm@yahoo.com.br

${ }^{3}$ Eng $^{\circ}$ Agrônomo, Prof. Titular, Departamento de Fitossanidade, Engenharia Rural e Solos, Faculdade de Engenharia, UNESP, Ilha Solteira - SP, malcolm@agr.feis.unesp.br

${ }^{4}$ Eng ${ }^{\circ}$ Agrônomo, Mestre em Agronomia (Sistemas de Produção), Faculdade de Engenharia, UNESP, Ilha Solteira - SP,

franciscocezarbl@gmail.com

${ }^{5}$ Eng $^{\circ}$ Agrônomo, Graduado em Agronomia, Faculdade de Engenharia, UNESP, Ilha Solteira - SP, ze_agrounesp@hotmail.com

${ }^{6}$ Eng $^{\circ}$ Agrônomo, Prof. Doutor, Departamento de Fitossanidade, Engenharia Rural e Solos, Faculdade de Engenharia, UNESP, Ilha

Solteira-SP, elcio@agr.feis.unesp.br
}

Recebido pelo Conselho Editorial em: 2-3-2012

Aprovado pelo Conselho Editorial em: 16-2-2014 


\section{INTRODUCTION}

The dynamics of macroeconomic changes occurred around the year 2,000 have been demanding changes in the Brazilian agricultural sector, by incorporating intensive processes in production systems, granting higher competitiveness and productivity to the demands imposed by society for the preservation of natural resources, mitigation of global weather impacts and food safety (BARCELLOS et al., 2008).

In this context, the production of integrated crop livestock system (ICL), especially when associated with the Direct Planting System (DPS), provides numerous benefits to producers and the environment by joining agronomic, economic, social and environmental factors (GALHARTE \& CRESTANA, 2010). MELLO et al. (2004) defined ICL as a system that integrates both activities with the goals of rationally maximizing land use through resources and benefits that one activity provides to the other.

DPS sustainability in great part of São Paulo State and Brazilian Central-West faces limitations due to the low straw production during autumn/ winter and winter/spring, concerning unfavorable climatic conditions (low water availability, characterized by dry winter season). Thus, corn and forage intercropping system provides straw for DPS and cattle feed availability for nutritional maintenance using the corn silage (BARDUCCI et al., 2009) that stands out due to its great dry matter productivity, good nutritional value and digestibility (OLIVEIRA et al., 2007).

The seeding of forage grasses, intercropped with corn, has shown good results with regard to the amount of straw produced. However, this practice requires studies to establish which is the best forage species or cultivar to be used in intercropping method, the best sowing time for forage during corn cycle (BORGHI \& CRUSCIOL, 2007) and the behavior of these intercrops in fall harvest when the goal is silage production.

This study aimed to evaluate the intercropping of four forage species with autumn corn, in three sowing modes, with emphasis on corn production for silage and straw contribution to DPS.

\section{MATERIAL AND METHODS}

The experiment was conducted in autumn/ winter of 2010 at the Education, Research and Extension Farm belonging to the College of Engineering, UNESP, campus Ilha Solteira located in Selvíria - MS at a local altitude of 350 meters and 4\% declivity and local climate is characterized as tropical humid with the rainy season in summer and dry in winter. The average temperature and rainfall during the experimental period, from May to September 2010 , were $23.8{ }^{\circ} \mathrm{C}$ and $30.7 \mathrm{~mm}$, respectively. The water supply performed by a central pivot.

The soil was classified as Dystrophic Red Latosol (EMBRAPA, 2006) (Dystrophic Red Oxisol by U.S. Soil Taxonomy). The initial chemical attributes, in the 0.0 to $0.3 \mathrm{~m}$ layer were $\mathrm{pH}$ $\left(\mathrm{CaCl}_{2}\right)=4.9 ; \mathrm{MO}=21 \mathrm{~g} \mathrm{dm}^{-3} ; \mathrm{H}+\mathrm{Al}=35 \mathrm{mmol}_{\mathrm{c}} \mathrm{dm}^{-3} ; \mathrm{P}($ resin $)=20 \mathrm{mg} \mathrm{dm}^{-3} ; \mathrm{V}=41 \%$; and $\mathrm{K}^{+}$, $\mathrm{Ca}^{2+}$ and $\mathrm{Mg}^{2+}=32.4 \mathrm{mmol}_{\mathrm{C}} \mathrm{dm}^{-3}, 13 \mathrm{mmol}_{\mathrm{C}} \mathrm{dm}^{-3}$ and $8 \mathrm{mmol}_{\mathrm{C}} \mathrm{dm}^{-3}$, respectively.

The area had been conducted under DPS for ten years and soybean was the previous crop. Treatments consisted of four forage species: E1: Urochloa brizantha cv. Marandu; E2: Urochloa ruziziensis cv. Ruziziensis; E3: Panicum maximum cv. Tanzânia and E4: Panicum maximum cv. Áries, intercropped with corn.

Additionally, three forage sowing modes were performed. One when corn was sown together with forage at same sowing row deposited with fertilizer at $6 \mathrm{~cm}$ depth (M1). A second one corn was sown together with forage, which was thrown over total area, on the same day (M2). A third one, corn sown then forage throw sown at the time of corn top dressing, which was at V4 stage (M3). Finally, corn without intercropping (control) (MS).

The statistical design used was the randomized block design in a factorial $(4 \times 3+1)$ with four replications. Each experimental plot consisted of seven corn rows spaced at $0.45 \mathrm{~m}, 18 \mathrm{~m}$ long and 
15-m crop track between the experimental blocks for machine maneuvering. For the experiment implementation, we used a pulling seeder-fertilizer machine with a pneumatic distribution system, configured with front cut discs, trenchers for fertilizer deposition of rod type and mismatched double disc for seeding depositing with "V" press wheels.

The experimental area was desiccated on May 10, 2010 with $1.92 \mathrm{~kg} \mathrm{ha}^{-1}$ glyphosate (a.i.) for weed control. We used the simple corn hybrid DKB 390 YG sown on May 19, 2010 aiming to target a population stand of 60,000 plants ha ${ }^{-1}$.

In intercropping $11 \mathrm{~kg} \mathrm{ha}^{-1}$ certified seeds of each forage with crop value of $35 \%$ were directly sown manually. Mineral fertilization at sowing furrows was carried out with $300 \mathrm{~kg} \mathrm{ha}^{-1}$ of the 08-28-16 commercial formula and topdressing in V4 corn stage, with $72 \mathrm{~kg} \mathrm{ha}^{-1} \mathrm{~K}_{2} \mathrm{O}$ and 135 $\mathrm{kg} \mathrm{ha}^{-1}$ of N. For weed control $1 \mathrm{~kg} \mathrm{ha}^{-1}$ of atrazine (a.i.), and $161.2 \mathrm{~g} \mathrm{ha}^{-1}$ of 2.4-D dimethyl amine (a.i.) applied on June 29, 2010.

The following evaluations were performed in the corn: initial and final stand population, on 5meter-long line of the three central rows; plant height and basal stem diameter, for 10 plants per plot. The assessment of corn silage production was held on September 25, 2010, by collecting the plants from each plot area (three 5-meter-rows), on R5 stage at $20 \mathrm{~cm}$ from the soil. The collected plants were weighed and the values transformed to determine green mass yield $\left(\mathrm{kg} \mathrm{ha}^{-1}\right)$; then, they were crushed and a sample collected, weighed (wet mass) and placed in a forced air circulation oven at $65{ }^{\circ} \mathrm{C}$ for 72 hours, and subsequently weighed again (dry mass) for calculating the dry matter (DM) yield for silage $\left(\mathrm{kg} \mathrm{DM} \mathrm{ha}^{-1}\right)$. Forage dry matter productivity was assessed on September 25, 2010 employing method used to calculate corn silage dry matter, by collecting two samples per plot at ground level, using a $0.25-\mathrm{m}^{2}$ iron frame.

The data were submitted to "F" test through the Assistat software (SILVA \& AZEVEDO, 2002) and the Tukey test was performed $(p<0.05)$ to compare the factor averages. Dunnett test ( $p$ $<0.05$ ) was also used to compare all treatments with the control.

\section{RESULTS AND DISCUSSION}

Data for plant height, basal stem diameter, initial and final plant stand of corn crop evaluated for forage and sowing modes are shown in Table 1. Results for plant attributes showed no significant differences in terms of applied treatments, nor for interaction. It might be happened due to corn emergence and early growth being faster than forage. In addition, there was no interference in crop development, what corroborated with FREITAS et al. (2008), who highlight corn as a great competitor to smaller plants such as Brachiaria. This is mainly due to its significant advantage over the forage, as evidenced by the higher accumulation rate of dry matter produced in early stages, so that there is no competition between intercrop species, Urochloa/ corn and Panicum/corn.

JAKELAITIS et al. (2010), evaluating corn cultivar performance (AL Bandeirantes, AG 2040 and Pioneer 30F87) and forage (Marandu and Xaraés U. brizantha, and Mombasa and Tanzânia, P. maximum) using intercropping and sole crop, spaced $1 \mathrm{~m}$ between rows and forage sowed at throw sowing simultaneously with corn. They did not observe any significant effect of corn and forage interaction on cultivars related to plant and corn ear height, stem diameter and final plant population; however, there was significant effect between corn cultivars for cultivar AL Bandeirantes highlighted with taller plants when compared to the others.

Plant height usually has no correlation with production, as modern cultivars with high yield potential are mostly short sized, but similar performance can be observed for cultivars of tall or short size (CRUZ et al., 2008). It is noteworthy that higher plants accumulate more nutrients, which can be translocated to the ears at the time of grain filling, and also after harvest, depositing greater amount of straw on the ground (PARIZ et al., 2011) and if they are intended for silage, they may generate greater amount of dry matter. Plant height values obtained in this experiment were above average, from 2.2 to $2.4 \mathrm{~m}$, indicated by the hybrid producing company. 
TABLE 1. Average values for plant height - PH (m), stem basal diameter - SBD (mm), initial stand- EI, and final stand - EF (plants ha ${ }^{-1}$ ) for intercropping cultivation of corn and four forage species in three planting modalities.

\begin{tabular}{llcccc}
\hline & Variation factor & PH & SBD & EI & EF \\
\hline \multirow{4}{*}{ Forage species } & U. brizantha cv. Marandu & 2.65 & 24.40 & 64,815 & 62,963 \\
& U. ruziziensis cv. Ruziziensis & 2.59 & 24.62 & 66,204 & 62,037 \\
& P. maximum cv. Tanzânia & 2.66 & 24.64 & 64,352 & 58,951 \\
& P. maximum cv. Áries & 2.62 & 24.42 & 65,278 & 59,259 \\
\hline \multirow{2}{*}{ Modes } & Line & 2.63 & 24.64 & 60,060 & 58,333 \\
& Throw sowing & 2.62 & 24.18 & 69,097 & 61,343 \\
& Throw sowing V4 & 2.65 & 24.74 & 64,583 & 59,954 \\
\hline \multirow{2}{*}{ F value } & Forages (F) & $1.6442^{\mathrm{ns}}$ & $0.1297^{\mathrm{ns}}$ & $0.3739^{\mathrm{ns}}$ & $2.7740^{\mathrm{ns}}$ \\
& Modes (M) & $0.5980^{\mathrm{ns}}$ & $0.9270^{\mathrm{ns}}$ & $2.7881^{\mathrm{ns}}$ & $0.5924^{\mathrm{ns}}$ \\
& Interaction (F X M) & $1.2782^{\mathrm{ns}}$ & $0.4202^{\mathrm{ns}}$ & $1.4023^{\mathrm{ns}}$ & $1.1458^{\mathrm{ns}}$ \\
\hline \multirow{2}{*}{ MSD } & Species & 0.09 & 1.35 & 11,883 & 8,602 \\
& Modes & 0.07 & 1.06 & 9,335 & 6,758 \\
\hline \multirow{2}{*}{ VC (\%) } & & 3.1 & 5.0 & 16.6 & 13.1 \\
\hline
\end{tabular}

${ }^{\mathrm{ns}}$ (non-significant). Averages followed by same letter do not differ of each other by Tukey test $(\mathrm{p}<0.05)$.

Similarly, according to PARIZ et al. (2011), regarding stem diameter, plants with finer stems have lower nutrient translocation capacity and become more susceptible to tipping by wind, rain and traffic of machines and equipment during operations. In this study, the mean value of $24.55 \mathrm{~mm}$ for basal stem diameter is considered high, and this fact added to plant height may have favored for high dry matter productivity of corn silage.

Data for corn silage and forage dry matter yield are presented in Table 2. Corn data had significance by the F Test $(\mathrm{p}<0.05)$ in the interaction between studied factors, whose post-analysis is presented in Table 3. Nevertheless, differences in deployment were not detected by the Tukey Test $(\mathrm{p}<0.05)$; therefore, intercropping averages between forage and applied modes were similar. However, a variation in corn silage yield from 22,992 kg DM ha ${ }^{-1}$ in intercropping with $P$. maximum cv. Tanzania seeded simultaneously at corn sowing day to $17,148 \mathrm{~kg} \mathrm{DM} \mathrm{ha}^{-1}$ in intercropping with $U$. ruziziensis $\mathrm{cv}$. Ruziziensis sown at corn row, both higher values than the regional average, which is around $15 \mathrm{t} \mathrm{DM} \mathrm{ha}^{-1}$.

TABLE 2. Average values of corn silage yield - SY (kg DM ha $\left.{ }^{-1}\right)$ and dry matter forage - DMF (kg $\mathrm{ha}^{-1}$ ) of four forages intercropped with corn in three planting modes.

\begin{tabular}{|c|c|c|c|}
\hline & Variation factor & SY & DMF \\
\hline \multirow{4}{*}{ Forage species } & U. brizantha cv. Marandu & 20,433 & 1,675 \\
\hline & U. ruziziensis cv. Ruziziensis & 20,068 & 1,975 \\
\hline & P. maximum cv. Tanzânia & 20,421 & 1,825 \\
\hline & P. maximum cv. Áries & 20,821 & 1,475 \\
\hline \multirow{3}{*}{ Modes } & Line & 20,359 & $2,256 \mathrm{a}$ \\
\hline & Throw sowing & 20,949 & $1,875 \mathrm{a}$ \\
\hline & Throw sowing V4 & 19,999 & $1,081 \mathrm{~b}$ \\
\hline \multirow{3}{*}{ F value } & Forages (F) & $0.1368^{\text {ns }}$ & $1.8914^{\mathrm{ns}}$ \\
\hline & Modes (M) & $0.4430^{\mathrm{ns}}$ & $19.8618 * *$ \\
\hline & Interaction $(\mathrm{F} \times \mathrm{M})$ & $2.5228 *$ & $0.7118^{\mathrm{ns}}$ \\
\hline \multirow{2}{*}{ MSD } & Species & 3,165 & 594 \\
\hline & Modes & 2,487 & 466 \\
\hline VC (\%) & & 14.1 & 31.0 \\
\hline
\end{tabular}


TABLE 3. Average values for corn silage yield post-analysis (kg DM ha-1) as a result of forages and sowing mode interactions.

\begin{tabular}{lccc}
\hline \multicolumn{1}{c}{ Forages } & \multicolumn{3}{c}{ Modes } \\
\cline { 2 - 4 } & Line & Throw sowing & Throw sowing V4 \\
\hline U. brizantha cv. Marandu & $22,439 \mathrm{aA}$ & $19,319 \mathrm{aA}$ & $19,542 \mathrm{aA}$ \\
U. ruziziensis cv. Ruziziensis & $17,148 \mathrm{aA}$ & $21,778 \mathrm{aA}$ & $21,276 \mathrm{aA}$ \\
P. maximum cv. Tanzânia & $20,224 \mathrm{aA}$ & $22,992 \mathrm{aA}$ & $18,047 \mathrm{aA}$ \\
P. maximum cv. Áries & $21,624 \mathrm{aA}$ & $19,705 \mathrm{aA}$ & $21,132 \mathrm{aA}$ \\
\hline MSD column & \multicolumn{3}{c}{5,483} \\
MSD line & 4,974 & \\
\hline
\end{tabular}

Averages followed by the same letter, capital letter for lines and lower case for columns, do not differ to each other by Tukey test $(\mathrm{p}<0.05)$.

PAZIANI et al. (2009) aiming to establish correlations between quantitative and qualitative characteristics and evaluate their influence on corn silage yield and quality, found that the highest dry matter yields in the studied sites were mainly caused by corn environment and cultivar supportive to dry matter and grain productions. Corn plant size, represented by plant and ear height, presented high correlation coefficient with dry matter production; therefore, corn phenotypical traits are able to determine the silage potential production. However, in this study forage and intercropping type did not influence the phenotypic characteristics or corn silage yield in any studied combination. It is worth noting that the current corn hybrid is indicated for cerrado region (savannah like vegetation), especially for regions with altitude levels below $700 \mathrm{~m}$, as in this case.

Moreover, according to PAZIANI et al. (2009), dry matter yield average of $18.69 \mathrm{t} \mathrm{ha}^{-1}$ obtained in different corn cultivars can be considered as very good when compared to realistic averages, which presents a range from 11.46 to $17.26 \mathrm{t} \mathrm{DM} \mathrm{ha}^{-1}$, lower than the result obtained in this study (average of $20.4 \mathrm{t} \mathrm{DM} \mathrm{ha}^{-1}$ ).

For forage dry matter yield, differences have occurred only based on sowing modes, not due to the species used (Table 2). When sown in corn row and at simultaneous throwing, corn sowing showed higher yield, exceeding on average $984 \mathrm{~kg} \mathrm{ha}^{-1}$ the throw sowing mode at V4 corn stage. These results can be explained since there is an increased competition between corn plants and forage, which when sown late in relation to crop growth experiences more difficulty to overcome competition for water, light and nutrients, besides suffering shading effects from the crop already established (BARDUCCI et al., 2009).

Furthermore, this above mentioned competition did not affect silage yield, contradicting the results of CHIODEROLI et al. (2010), who found higher dry matter yield when Brachiaria was sown between corn rows, differing from the modes with row intercropping on the corn sowing day and at throw sowing at topdressing time, and this difference reflected in higher corn grain yield.

For intercropping carried out with throw sowing at V4 corn stage, besides the increased competition exerted by the crop on the forage, the lack of seed incorporation can also be a limiting factor. Once the merger benefits plant germination and survival due to seed protection, to the efficiency in moisture usage and ease of seedling fixation to the soil (MOTA et al., 2010). Factors that together can have caused lower dry matter yield in this type of intercropping, the forage mixed with fertilizer sown at $6 \mathrm{~cm}$ depth and the sown at throw sowing simultaneously to corn, despite not being incorporated, suffered less competition exerted by corn.

PARIZ et al. (2011), evaluating four Brachiaria species intercropped in the row and at throw sowing at corn sowing time reported that, although satisfactory, forage dry matter yield (above $2,500 \mathrm{~kg} \mathrm{ha}^{-1}$ ). Except for $U$. brizantha, the other species intercropped at throw sowing were superior to the ones intercropped on the row, especially $U$. decumbens e $U$. ruziziensis with greater adaptability and forage productivity in the intercropping with corn in the farming-cattle breeding integration system. 
The results of corn characteristics, comparing corn intercropping treatments and the ones without intercropping (control) are shown in Table 4. Data showed no significant differences by the Dunnett's Test ( $\mathrm{p}<0.05$ ), so there were no differences between control and other treatments used. It may be because the experimental area has been under DPS for ten years; it is possible that during this period a soil restructuring has occurred, through the development of this management system, as a result of the permanent presence of biomass on soil, which contributes to organic matter maintenance.

CORREIA et al. (2011) when assessing corn and $P$. maximum intercropping in two arrangements, in row and at throw sowing; observed no significant effect of sowing modes on corn height, dry matter yield, plant population, number of ears, mass of 400 grains and grain productivity. Thus, intercropping did not influence the corn plant development compared to single corn grow corroborating with the current study.

TABLE 4. Average values for plant height - PH (m), stem basal diameter - SBD (mm), initial stand- EI and final stand - EF (plants ha ${ }^{-1}$ ) and corn silage yield - SY (kg DM ha ${ }^{-1}$ ) in corn intercropped with four forage species in three planting modes and in corn without intercropping.

\begin{tabular}{|c|c|c|c|c|c|c|}
\hline \multicolumn{2}{|l|}{ Treatments } & \multirow{2}{*}{$\mathrm{PH}$} & \multirow{2}{*}{ SBD } & \multirow{2}{*}{ EI } & \multirow{2}{*}{$\mathrm{EF}$} & \multirow{2}{*}{ SY } \\
\hline Species & Modes & & & & & \\
\hline U. brizantha cv. Marandu & Line & 2.65 & 24.67 & 59,722 & 62,037 & 22,439 \\
\hline U. brizantha cv. Marandu & T. sowing & 2.64 & 24.31 & 63,889 & 62,963 & 19,319 \\
\hline U. brizantha cv. Marandu & T. sowing V4 & 2.67 & 24.24 & 70,833 & 63,889 & 19,542 \\
\hline U. ruziziensis cv. Ruziziensis & Line & 2.61 & 24.92 & 59,722 & 48,148 & 17,148 \\
\hline U. ruziziensis cv. Ruziziensis & T. sowing & 2.51 & 23.76 & 69,445 & 57,408 & 21,778 \\
\hline U. ruziziensis cv. Ruziziensis & T. sowing V4 & 2.66 & 25.18 & 70,833 & 59,259 & 21,277 \\
\hline P. maximum cv. Tanzânia & Line & 2.66 & 24.48 & 61,112 & 61,111 & 20,224 \\
\hline P. maximum cv. Tanzânia & T. sowing & 2.69 & 24.31 & 65,278 & 57,408 & 22,972 \\
\hline P. maximum cv. Tanzânia & $\mathrm{T}$. sowing V4 & 2.63 & 25.14 & 59,723 & 58,334 & 18,047 \\
\hline P. maximum cv. Áries & Line & 2.60 & 24.49 & 77,778 & 62,037 & 21,624 \\
\hline P. maximum cv. Áries & T. sowing & 2.63 & 24.36 & 56,945 & 67,592 & 19,705 \\
\hline P. maximum cv. Áries & T. sowing V4 & 2.63 & 24.40 & 56,945 & 58,333 & 21,132 \\
\hline Control treatment & & 2.67 & 24.96 & 69,445 & 58,333 & 19,778 \\
\hline F value - Fatorial x Control & & $0.9142^{\mathrm{ns}}$ & $0.4654^{\mathrm{ns}}$ & $0.7462^{\mathrm{ns}}$ & $0.1435^{\mathrm{ns}}$ & $0.1922^{\mathrm{ns}}$ \\
\hline MSD & & 0.17 & 2.53 & 22,301 & 16,144 & 5,941 \\
\hline VC (\%) & & 3.12 & 5.00 & 16.65 & 13.10 & 14.13 \\
\hline
\end{tabular}

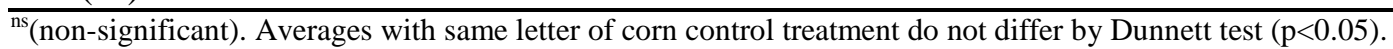

BARDUCCI et al. (2009) when evaluating five cropping systems (sole corn, corn with $U$. brizantha cv. Marandu intercropped at sowing and topdressing, corn with P. maximum cV. Mombasa intercropped at sowing and at topdressing) found that the corn grain yield was influenced by cropping systems and mainly by the forage species, since the corn intercropping with $P$. maximum cv. Mombasa provided the greatest variations. The intercrop cultivation system simultaneous to sowing had lower grain yield and intercropping carried out during topdressing fertilization had bigger yield too. The grain yield values for corn intercropping with $U$. brizantha were significantly intermediate compared to sole corn crop, which the largest increase in productivity occurred in intercropping with $P$. maximum in coverage.

In contrast, LEONEL et al. (2009) tested corn intercropping with $U$. brizantha varied cultivation system, in row and between corn rows, and brachiaria and corn in sole cultivation, in order to contrast their yield with the different intercrop arrangements. The authors claimed that corn productivity was not affected by intercropping with brachiaria, not differing from the corn sole 
cultivation. However, they highlighted the importance sowing two brachiaria rows between corn rows, spaced $1 \mathrm{~m}$ apart, when the objective is to reform degraded pastures.

\section{CONCLUSIONS}

Given the benefits of intercropping and the straw supply purpose for DPS continuity, the autumnal corn intercropping with forage should be chosen, since corn silage production was not affected by the system.

Corn intercropping is recommended with any of the studied forage species, Urochloa brizantha cv. Marandu, Urochloa ruziziensis cv. Ruziziensis, Panicum maximum cv. Tanzânia and Panicum maximum cv. Áries, with a preference for the row sowing mode thrown over, together with fertilizer to seize same operation.

\section{ACKNOWLEGEMENTS}

We want to thank the Agrisus Foundation for the financial support to the research.

\section{REFERENCES}

BARCELLOS, A.O.; RAMOS, A.K.B.; VILELA, L.; MARTHA JÚNIOR, G.B. Sustentabilidade da produção animal baseada em pastagens consorciadas e no emprego de leguminosas exclusivas, na forma de banco de proteína, nos trópicos brasileiros. Revista Brasileira de Zootecnia, Viçosa, MG, v.37, p.51-67, 2008. Suplemento especial

BARDUCCI, R.S.; COSTA, C.; CRUSCIOL, C.A.C.; BORGHI, É.; PUTAROV, T.C.; SARTI, L.M.N. Produção de Brachiaria brizantha e Panicum maximum com milho e adubação nitrogenada. Archivos de Zootecnia, Cordoba, v.58, n.222, p.211-222, 2009.

BORGHI, É.; CRUSCIOL, C.A.C. Produtividade de milho, espaçamento e modalidade de consorciação com Brachiaria brizantha no sistema plantio direto. Pesquisa Agropecuária Brasileira, Brasília, v.42, n.2, p.163-171, 2007.

CHIODEROLI, C.A.; MELLO, L.M.M.; GRIGOLLI, P.J.; SILVA, J.O.; CESARIN, A.L. Consorciação de braquiárias com milho outonal em plantio direto sob pivô central. Engenharia Agrícola, Jaboticabal, v.30, n.6, p.1101-1109, 2010.

CORREIA, N.M.; LEITE, M.B.; DANIEL, B. Efeito do consórcio de milho com Panicum maximum na comunidade infestante e na cultura da soja em rotação. Planta Daninha, Viçosa, MG, v.29, n.3, p.545-555, 2011.

CRUZ, S.C.S.; PEREIRA, F.R.S.; SANTOS, J.R.; ALBUQUERQUE, A.W.; PEREIRA, R.G. Adubação nitrogenada para o milho cultivado em sistema plantio direto, no Estado de Alagoas. Revista Brasileira de Engenharia Agrícola e Ambiental, Campina Grande, v.12, n.1, p.62-68, 2008.

EMBRAPA. Empresa Brasileira de Pesquisa Agropecuária. Sistema brasileiro de classificação dos solos. 2.ed. Rio de Janeiro: CNPS, 2006. 306p.

FREITAS, F.C.L.; SANTOS, M.V.; MACHADO, A.F. L.; FERREIRA, L.R.; FREITAS, M.A.M.; SILVA, M.G.O. Comportamento de cultivares de milho no consórcio com Brachiaria brizantha na presença e ausência de foramsulfuron + iodosulfuron methyl para o manejo da forrageira. Planta Daninha, Viçosa, MG, v.26, n.1, p.215-221, 2008.

GALHARTE, C.A.; CRESTANA, S. Avaliação do impacto ambiental da integração lavourapecuária: Aspecto conservação ambiental no cerrado. Revista Brasileira de Engenharia Agrícola e Ambiental, Campina Grande, v.14, n.11, p.1202-1209, 2010.

JAKELAITIS, A.; DANIEL, T.A.D.; ALEXANDRINO, E.; SIMÕES, L.P.; SOUZA, K.V.; LUDTKE, J. Cultivares de milho e de gramíneas forrageiras sob monocultivo e consorciação. Pesquisa Agropecuária Tropical, Goiânia, v. 40, n. 4, p. 380-387, 2010. 
LEONEL, F.P.; PEREIRA, J.C.; COSTA, M.G.; MARCO JÚNIOR, P.; LARA, L.A.; QUEIROZ, A.C. Comportamento produtivo e características nutricionais do capim braquiária cultivado em consórcio com milho. Revista Brasileira de Zootecnia, Viçosa, MG, v.38, n.1, p.177-189, 2009.

MELLO, L.M.M.; YANO, E.H.; NARIMATSU, K.C.P.; TAKAHASHI, C.M.; BORGHI, E. Integração agricultura-pecuária em plantio direto: produção de forragem e resíduo de palha após pastejo. Engenharia Agrícola, Jaboticabal, v.24, n.1, p.121-129, 2004.

MOTA, V.A.; SANTOS, L.D.T.; SANTOS JUNIOR, A.; MACHADO, V.D.; SAMPAIO, R.A.; OLIVEIRA, F.L.R. Dinâmica de plantas daninhas em consórcio de sorgo e três forrageiras em um sistema de integração lavoura-pecuária-floresta. Planta Daninha, Viçosa, v.28, n. 4, p. 759-768, 2010.

OLIVEIRA, J.S.; SOUZA SOBRINHO, F.; REIS, F.A.; SILVA, G.A.; ROSA FILHO, S.N.; SOUZA, J.J.R.; MOREIRA, F.M.; PEREIRA, J.A.; FIRMINO, W.G. Adaptabilidade e estabilidade de cultivares de milho destinados à silagem em bacias leiteiras do Estado de Goiás. Pesquisa Agropecuária Tropical, Goiânia, v.37, n.1, p.45-50, 2007.

PARIZ, C.M.; ANDREOTTI, M.; AZENHA, M.V.; BERGAMASCHINE, A.F.; MELLO, L.M. M.; LIMA, R. C. Produtividade de grãos de milho e massa seca de braquiárias em consórcio no sistema de integração lavoura-pecuária. Ciência Rural, Santa Maria, v.41, n.5, p.875-882, 2011.

PAZIANI, S.F.; DUARTE, A.P.; NUSSIO, L.G.; GALLO, P.B.; BITTAR, C.M.M.;

ZOPOLLATTO, M.; RECO, P.C. Características agronômicas e bromatológicas de híbridos de milho para produção de silagem. Revista Brasileira de Zootecnia, Viçosa, MG, v.38, n.3, p.411417, 2009.

SILVA, F. de A.S.; AZEVEDO, C.A.V. de. Versão do programa computacional Assistat para o sistema operacional Windows. Revista Brasileira de Produtos Agroindustriais, Campina Grande, v.4, n.1, p.71-78, 2002. 